\title{
The Making of a Transnational Religion:
}

\section{Alevi Movement in Germany and the World Alevi Union}

Derya Özkul

University of Oxford

Correspondence details:

Dr Derya Ozkul

Refugee Studies Centre, Department of International Development, University of Oxford Queen Elizabeth House, 3 Mansfield Road, Oxford OX1 3TB

Tel: 01865 (2)71903

Email: derya.ozkul@qeh.ox.ac.uk 


\section{The Making of a Transnational Religion:}

\section{Alevi Movement in Germany and the World Alevi Union}

The literature on migrants' religious movements generally see them as backward and conservative movements that are resistant to change. On the contrary, this paper shows that transnational religious movements are shaped by interactions between origin and destination places' political, legal, and social structures, and may take different pathways across time and place. Analysing the development of the Alevi diaspora movement in Germany and the recent efforts to establish the World Alevi Union, the article argues that both the (old and new) states and the (old and new) societies they live in, as well as broader paradigm changes and their agency have a direct influence on the ways migrants' daily life practices alter in time.

Keywords: transnationalism, diaspora, religion, Alevi, Turkey, Germany, institutionalisation

\section{Introduction}

History shows that migration is a catalyser for change both in destination and origin places: migrants bring new ways of thinking and doing things to the places they arrive, are transformed by the existing structures of their new societies and also bring about changes in their origin countries - either by their absence or by bringing these transformations. Such transnational interactions do not only bring about political, economic and social change, they also significantly impact spiritual lives. As Peggy Levitt observe, migrants bring their faith and practices with them when they migrate and change the religious landscape in their new countries. ${ }^{1}$ While they change their new societies, their own practices might also change in

\footnotetext{
${ }^{1}$ Peggy Levitt, “"You know, Abraham was really the first immigrant”: Religion and transnational migration', International Migration Review 37, no. 3 (2003): 847-73. Peggy Levitt, 'Religion on the move', in Religion on the edge: decentering and recentering the sociology of religion, ed. C. Bender, W. Cadge, P. Levitt and D. Smilde (Oxford: Oxford University Press, 2013), 159-76.
} 
time according to their newly emerging needs, as well as unavoidable broader paradigm changes.

This article seeks to explore the changes in spiritual practices during the process of migration and settlement in new places. The motivating research questions are: how do migrants - in this case Alevi migrants from Turkey-experience and practice their faith away from their hometowns, how do they express it for outsiders, and how do their faiths change along with their changing surroundings including new political, legal and social structures? Put more abruptly, how does a faith system change through migration abroad and through continuing transnational interactions between migrants and those in the homeland? By looking at the case of Alevi migrants abroad, this article particularly aims to examine the processes that led to the emergence of a transnationally institutionalised Alevism through the recent initiatives to establish the World Alevi Union.

This examination raises various theoretical questions over the relationship between migration and religion, such as who gets to define the boundaries of a religion and under which legislative and political structures they can do that, which will be explored further. Even though there is extensive literature on global religious pluralism ${ }^{2}$, and on new religious movements ${ }^{3}$, there is very little examination of the processes of institutionalisation of transnational religions. Exploring the case of a transnational Alevi movement, the article argues that the changes in practices can only be studied by looking at the structures of the new place of residence and those of the origin place where migrants resided, acculturated and where they still have close family members and friends, as well as broader paradigm changes

\footnotetext{
2 Thomas Banchoff, ed., Democracy and the New Religious Pluralism (Oxford: Oxford University Press, 2008). Roger Boase, ed., Islam and Global Dialogue: Religious Pluralism and the Pursuit of Peace (Surrey: Ashgate, 2010).

${ }^{3}$ James R. Lewis and Inga Tollefsen, eds., The Oxford Handbook of New Religious Movements (Oxford: University of Oxford Press, 2016). Derya Özkul. 'Alevi “Openings” and Politicization of the "Alevi Issue” During the AKP Rule’, Turkish Studies 16, no. 1 (2015): 80-96.
} 
and migrants’ agency.

\section{A Multi-Scalar Approach to Transformation of Diasporas}

This article employs a social constructionist approach towards Alevi migrants considering them as a diaspora group who mobilised against injustices in Turkey and in their new countries. A social constructionist approach regards diasporas as mobilised and fabricated social entities, as suggested by Sökefeld ${ }^{4}$ and Adamson ${ }^{5}$. Contrary to primordialist definitions of ethnic identity, Sökefeld ${ }^{6}$ proposes that the formation of a diaspora, as an imagined transnational community ${ }^{7}$, is not a natural and inevitable consequence of migration but an outcome of specific mobilisation processes in response to particular events. Adamson suggests that diasporas can best be analysed as 'the products or outcomes of transnational mobilization activities by political entrepreneurs engaged in strategic social identity construction’. ${ }^{8}$ In this approach, ““diaspora” is not simply a descriptive term, but also a prescriptive term, which can be adapted as a means of creating a de-territorialised social, cultural or political community'. ${ }^{9}$

The existing literature often posits diasporas as an extension of the homeland population, but in reality, diasporas are different actors than their counterparts in the homeland; they are nourished from different sources and they go through different conceptualisation processes. Hence a diasporic individual or community may acquire

\footnotetext{
${ }^{4}$ Martin Sökefeld. 2006. 'Mobilizing in transnational space: a social movement approach to the formation of diaspora’, Global Networks 6, no. 3 (2006): 265-84.

${ }^{5}$ Fiona Adamson, 'Constructing the Diaspora: Diaspora Identity Politics and Transnational Social Movements' (paper presented at the 49th annual meeting for the International Studies Association, San Francisco, CA, March 6-29, 2008).

${ }^{6}$ Sökefeld, Mobilizing in transnational space, 280.

${ }^{7}$ Benedict Anderson, 1991. Imagined Communities: Reflections on the Origin and Spread of Nationalism (London: Verso, 1991).

Salman Rushdie, The Ground beneath Her Feet (New York: Henry Holt, 1999).

${ }^{8}$ Adamson, Constructing the Diaspora, 2.

${ }^{9}$ Ibid., 7.
} 
different ideas, see the merits or shortcomings of their home countries from a different lens, and attach importance to and work for diverse issues. ${ }^{10}$ As much as they are affected by the developments in their homeland, they are also shaped by the conditions of their new societies, ${ }^{11}$ as well as how these conditions change over time. Consequently, they may initiate a completely divergent movement than their fellow compatriots in ways that may be unfeasible or unimaginable in the homeland. There are various factors one needs to explore to understand the emergence and transformation of a diaspora.

Firstly, host countries’ state practices—policies and discourses-towards their migrants provide opportunities (or obstacles) and have an important role in mobilising them. Migrants may want to make use of these opportunities to the extent they are integrated (or in order to be integrated) into the economic, political and social structures of their new societies. Host societies shape the collective organization of migrants by providing (or not) certain resources for and models of organizing. Some host polities afford explicit channels for the participation and organization of migrant populations, thereby affecting their selforganization. Certain host-society institutions and policies encourage collective identity and organization, by means of categorization and the provision of resources to ethnic groups. Migrant organizations, in turn, define their goals, strategies, functions, and level of operation in relation to the existing policies and resources of the host state. They advance demands and set agendas vis-à-vis state policy and discourses in order to seize institutional opportunities and further their claims. Hence, it is imperative to analyse the structural conditions of the country of residence.

\footnotetext{
${ }^{10}$ Ayhan Kaya, ‘German-Turkish Transnational Space: A Separate Space of Their Own’, German Studies Review 30, no. 3 (2007): 483-502.

${ }^{11}$ Milton J. Esman, Diasporas in the contemporary world (Cambridge: Polity Press, 2009), 181.
} 
Secondly, home states also play an important role in activating diasporas. For instance, since the 1990s, a growing number of governments has sought to reach their migrants abroad and mobilise diasporas in order to attract remittances or establish transnational business networks. ${ }^{12}$ Home states may also mobilise diasporas to obtain political support for government policies, especially in the case of a conflict between ethnic and/or religious groups. ${ }^{13}$ Indeed, some diasporas may be activated to join armed forces, as in the case of ISIS and the Syrian Armed Forces, while others play a role as peace-makers. ${ }^{14}$ Even if there is no conflict, home states might try to exclude some ethnic groups from accessing resources while supporting others, which may in turn mobilise migrants from that ethnic group living abroad to react against their home states. Home states may attempt not only to monitor the activities of migrants abroad but also to transform them in line with the dominant state ideology in order to keep their population under control. ${ }^{15}$ Diyanet Işsleri Türk İslam Birliği (DİTİB) [Turkish Islamic Union for Religious Affairs] is a good example of an origin country’s involvement in its diaspora. ${ }^{16}$ Hence, as Rainer Bauböck also suggests, diasporas have to be analysed through encounters occurring in the homeland. ${ }^{17}$

Thirdly, it is impossible to analyse the role of host and home states by themselves without considering the broader paradigm shifts. The emerging discourse around national

\footnotetext{
12 Beverley Mullings, ‘Diaspora strategies, skilled migrants and human capital enhancement in Jamaica’, Global Networks 11, no. 1 (2011): 24-42. Alan Gamlen, Michael Cummings, Paul M. Vaaler, and Laura Rossouw., 'Explaining the Rise of Diaspora Institutions' (Working Paper, no. 78, IMI, University of Oxford, Oxford, 2013).

${ }^{13}$ Laurie A. Brand, Citizens abroad: Emigration and the state in the Middle East and North Africa (Cambridge: Cambridge University Press, 2006).

${ }^{14}$ Bahar Başer and Ashok Swain, 'Diasporas as Peacemakers: Third Party Mediation in Homeland Conflicts', International Journal on World Peace 25, no. 3 (2008): 7-28. PILPG, Engaging Diaspora Communities in Peace Processes (Washington, DC: Public International Law \& Policy Group, 2009).

${ }^{15}$ Banu Şenay, Beyond Turkey's Borders: Long-distance Kemalism, State Politics and the Turkish Diaspora (London and New York.: I.B.Tauris, 2012).

${ }^{16}$ Benjamin Bruce, 'Not quite in, not quite out: Islamic organizations in France and Germany and their ties to their states of origin', in Islamic Organizations in Europe and the USA, ed. Matthias Kortmann and Kerstin Rosenow-Williams (London: Palgrave Macmillan, 2013), 129-49.

${ }^{17}$ Rainer Bauböck, 'Ties across borders: The growing salience of transnationalism and diaspora politics' (policy brief, no. 13, IMISCOE, Erasmus University Rotterdam, Rotterdam, 2008), 3.
} 
types of Islam, for instance German Islam, is 'shaped as much as by forces outside the nation as within it, because people and groups belong to transnational religious networks that exert their influence from far away'. ${ }^{18}$ It has been well-documented in the literature that since the 9/11 attacks in the USA, hatred towards migrants and in particular Islamophobia have increased in western countries ${ }^{19}$ with a growing perception of 'Western' and 'Islamic' countries as two opposite worlds, often ignoring the various differences among 'a billion Muslims, divided into over fifty states and into myriad ethnicities and social groups’.2021 Nonetheless, this paradigm shift has had an important impact for all migrants from Turkey, because since 9/11 they have increasingly been identified as Muslims. ${ }^{22}$

Fourthly, and finally, migrants themselves can be influenced by changes in their origin countries regardless of states' involvement in them. ${ }^{23}$ Both origin and new countries influence migrants’ broader perceptions and interpretations of life. ${ }^{24}$ Having witnessed new forms of social organisation—diversity policies, such as multiculturalism, or different models of secularism—migrants might change their previous opinions or perceptions of their homeland. Alevi migrants, having learned about different approaches to governance of

\footnotetext{
${ }^{18}$ Peggy Levitt, 'What's wrong with migration scholarship? A critique and a way forward', Identities: Global Studies in Culture and Power 19, no. 4 (2012): 495.

${ }^{19}$ Ayhan Kaya, 'Backlash of multiculturalist and republicanist policies of integration in the age of securitization', Philosophy \& Social Criticism 38, no. 4-5 (2012): 399-411.

${ }^{20}$ Fred Halliday, 'West encountering Islam: Islamophobia reconsidered', in Islam Encountering Globalization, ed. Ali Mohammadi (London: Routledge, 2002), 14.

${ }^{21}$ Moreover, the way communities perform their beliefs is often different in the diaspora context based on the level of their structural integration as well as whether they are first- or second-generation migrants, see Ayhan Kaya, Islam, migration and integration: the age of securitization (London: Palgrave, 2009). Ayhan Kaya, 'Individualization and Institutionalization of Islam in Europe in the Age of Securitization', Insight Turkey 12, no.1 (2010): 47-63.

${ }^{22}$ Levent Tezcan, 'Göç ve Uyum Politikalarında Din Dönüşümü', Die Gaste 22 (2012).

${ }^{23}$ Alynna J. Lyon and Emek M. Uçarer, 'Mobilizing ethnic conflict: Kurdish separatism in Germany and the PKK', Ethnic and Racial Studies 24, no. 6 (2001): 925-48. Martin Sökefeld, Struggling for recognition: The Alevi movement in Germany and in transnational space (New York: Berghahn Books, 2008).

${ }^{24}$ Jennifer M. Brinkerhoff, Digital Diasporas: Identity and Transnational Engagement (New York: Cambridge University Press, 2009), 7.
} 
distinct cultural and religious groups, might come to frame their claims differently compared with their counterparts in Turkey.

From this multi-scalar perspective, this article is based on two theoretical assumptions: first, it assumes that all cultures and faith systems are permeable to transform according to the changing structures in host and home countries, as well as paradigmatic changes and migrants’ altering needs and demands. Second, cultures and faith systems may evolve into a 'religion' following some political divisions. The social movement literature shows us that often political divisions first emerge among members of a social group: once a group among the dissidents becomes successful in leading the group, the institutionalisation stage starts—new rules, routines and directories are established. ${ }^{25}$ Using a social movement approach, Massicard ${ }^{26}$ and Sökefeld ${ }^{27}$ theorise the Alevi movement based on the political opportunity structures that activists_-in Massicard's terminology Alevists_operate in. Extending their work, this article shows that it is crucial to understand the initial political divisions, who become leaders, how they direct the movement and how they establish new routines and directories in order to understand the emergence of a transnational religious institution, such as that of the World Alevi Union. The following sections will show how the role of host and home countries, paradigm changes as well as Alevi migrants' emerging needs and framing contests have transformed the way they institutionalise.

\footnotetext{
${ }^{25}$ Donatella Della Porta, Democracy in Social Movements (New York: Palgrave, 2009).

${ }^{26}$ Elise Massicard, The Alevis in Turkey and Europe: identity and managing territorial diversity (New York: Routledge, 2012). Elise Massicard, 'Alevist Movements at Home and Abroad: Mobilization Spaces and Disjunction’, New Perspectives on Turkey 28 (2003): 163-88.

${ }^{27}$ Sökefeld, Struggling for recognition.
} 


\section{Changing Political Landscape in Turkey and Abroad}

The period since the 9/11 attacks in a number of Western countries witnessed the emergence of a discourse around the 'crisis of multiculturalism' ${ }^{28}$ and the previous problematisation of immigrants’ ethnic identities slowly gave way to the problematisation of their religion. Violent killings by the Islamic State of Iraq and Syria, carried out in the name of Islam, and continuing denigration of Muslim immigrants in mainstream media further tarnished the image of immigrants from Middle Eastern countries. A growing number of xenophobic groups, such as the newly established Patriotic Europeans against the Islamisation of the West (Pegida), have caused a great deal of distress among Muslim communities. ${ }^{29}$ In this socio-political environment in Western countries migration became immediately associated with threats to borders and national security.

Germany — where most Alevi migrants reside—witnessed similar changes, where religious (rather than ethnic) distinctions became crucial in identifying migrants’ backgrounds, ${ }^{30}$ paving the way for growing hatred of Muslims, whose internal heterogeneity was not widely understood. The attacks of 9/11, Madrid (2004) and London (2005) had a transnational effect, ${ }^{31}$ and issues associated with Islam (such as the wearing of headscarves, introduction of Islamic courses at schools, forced marriages and honour killings) became hot topics. The media quickly began describing Muslim men as oppressive, physically abusive in defence of their honour, traditional, undemocratic and ‘un-German’ and Muslim women as victims of oppression within their families. ${ }^{32}$ These simplistic stereotypes became

\footnotetext{
${ }^{28}$ Alana Lentin and Gavan Titley, The Crises of Multiculturalism (London: Zed Books, 2011).

${ }^{29}$ Nicholas De Genova, 'In the Land of the Setting Sun: Reflections on "Islamization” and "Patriotic Europeanism”', Movements: Journal für kritische Migrations- und Grenzregimeforschung [Journal for Critical Migration and Border Studies] 1, no. 2 (2015): 1-12.

30 Tezcan, Göç ve Uyum Politikalarında Din Dönüşümü.

31 Jocelyne Cesari., 'The Securitisation of Islam in Europe' (Challenge Research Paper, no.14, Brussels, 2009).

32 Naika Foroutan, Identity and (Muslim) Integration in Germany (Washington, DC, Migration Policy Institute 2013), 5-7. Heiner Bielefeldt, Das Islambild in Deutschland: Zum öffentlichen Umgang mit der Angst vor dem Islam (Berlin: Deutsches Institut für Menschenrechte, 2008).
} 
widespread, influencing public discourse, immigration policies and the imagination of nationhood. ${ }^{33}$ The new Immigration Act, for instance, facilitated deportation of so-called 'hate preachers', reflecting the assumption that immigrants were violent and threatened the German national imaginary. The growth of an anti-Islamic movement was also reflected in the emergence of aggressively anti-Muslim websites such as Politically Incorrect121, derogatory books by well-known figures such as Thilo Sarrazin ${ }^{34}$ and far-right political parties such as Pro Deutschland. Arson attacks on Muslims and nation-wide protests against the 'Islamisation of Europe' increased to such an extent that Chancellor Merkel of the Christian Democratic Union (CDU) was compelled to declare that anti-Muslim hatred was not acceptable in Germany. ${ }^{35}$

At the same time, however, some politicians began paying closer attention to Muslims' activities and demands in order to understand them. For instance, immediately after the new CDU-led government assumed power in 2005, the Minister of the Interior, Wolfgang Schäuble, initiated a series of Conferences on Islam. The first was organised in September 2006 and hosted representatives from diverse Muslim organisations (including Alevi Federation in Germany [AABF]) with the aims of creating an institutionalised contact point between the German state and Muslims, promoting gender equality as a common value, and preventing radicalism and social polarisation. ${ }^{36}$ This and subsequent meetings sought to build a platform for communication between the German state and Muslim groups via the newly

\footnotetext{
${ }^{33}$ Harald Bauder and Jan Semmelroggen, 'Immigration and Imagination of Nationhood in the German Parliament', Nationalism and Ethnic Politics 15, no. 1 (2009): 1-26. Katherine Pratt Ewing, Stolen Honor: Stigmatizing Muslim Men in Berlin (Redwood City, CA: Stanford University Press, 2008).

34 Thilo Sarrazin, Deutschland schafft sich ab: wie wir unser Land aufs Spiel setzen (Munich: Deutsche VerlagsAnstalt, 2010).

35 See Reuters, 'Merkel condemns racism as Dresden anti-Islam marches grow', 12 December 2014, http://goo.gl/zvK3ao (accessed 8 June 2018).

${ }^{36}$ AIK, 'AIK'nin Çalışma Programı - Idddialı ve Uygulama Odaklı' [The Work Plan of German Islam Conference - Ambitious and Practical], German Islam Conference, 2010, http://www.deutsche-islamkonferenz.de/DIK/TR/DIK/UeberDIK/Arbeitsprogramm/arbeitsprogramm-\%20node.html (accessed 8 June 2018).
} 
established Coordination Council of Muslims in Germany (KRM), the same model which already mediated relations between the state and the Protestant and Catholic churches. Given the diversity of Islamic groups, however, it became clear that the process of negotiation would not be easy, since not all of them recognised the others as true practitioners of Islam. The Alevi Federation (AABF) in particular attracted criticism from other Islamic groups on the basis that 'those who do not live Islam should not be part of the conference'. ${ }^{37}$ Both these paradigm shifts in German politics and the conflicts that emerged between representatives of different Islamic groups led to greater effort in the struggle for recognition of Alevism.

Simultaneously, Turkey—where Alevis originate from—also underwent major changes since the start of the millennium. Following an economic crisis of 2001/2002, the AKP administration rose to power as a new party promising changes in the political scene. Indeed, securing the majority of votes, the AKP government has gradually and profoundly changed the political, legal, economic and social conditions for Alevis in Turkey. Following some democratic 'openings' in the road to the EU membership, the AKP government also promised to make changes for Alevis to be able to practice their cultural and faith-related practices freely, while also clearly leaving them in limbo in the face of growing physical and verbal threats. As any other social group, Alevis were not a homogeneous group—some benefitted from the AKP's search for collaboration, but most remained under risk. ${ }^{38}$ Verbal and physical attacks (and threats of attacks) have continuously not been investigated by state authorities in Turkey deepening Alevis’ longstanding resentment and disenfranchisement. ${ }^{39}$

\footnotetext{
${ }^{37}$ Ali Ertan Toprak, Alevilerin Sesi 10 (2006): 18-19., pg. 18.

38 Özkul, 'Alevi "Openings" and Politicization of the "Alevi Issue” During the AKP Rule.

${ }^{39}$ Ayfer Karakaya-Stump, 'The AKP, sectarianism, and the Alevis' struggle for equal rights in Turkey', National Identities 20, no. 1 (2018): 53-67.
} 


\section{Struggles for Recognition from Nation-States}

Looking particularly at the case of Germany where the biggest number of Alevi migrants reside, in this section I show that throughout the 2000s, a large part of Alevi organisations chaged the framing of Alevism merely as an element of Turkish folk and began re-defining themselves as unique faith organisations. Firstly, in search for recognition, Alevi activists ${ }^{40}$ presented their movement to German authorities in opposition to Islamists as peaceful, egalitarian and modern. For instance, when German President Johannes Rau met with NGOs in Berlin immediately after the 9/11 attacks, the then president of Berlin AAKM, emphasised that they were totally opposed to terrorism. On 9 January 2002, a leading activist of AABF, also met with Rau and presented him with a detailed file of AABF activities. ${ }^{41}$

Secondly, some activists became deeply involved in newly established inter-faith groups, collaborating primarily with Christian groups-which are the dominant religious authorities in Germany_to fight against Islamist radicalisation. For example, AABF attended various initiatives organised by the Catholic Church for inter-faith dialogue. ${ }^{42}$ Through this relationship, the Catholic Church allowed AABF to distribute ashura $^{43}$ in front of Cologne Cathedral in the centre of the city. ${ }^{44}$ Berlin AAKM started working with the Catholic Academy ${ }^{45}$ right after 9/11; AABF later attended the symposium 'Interfaith Dialogue in Europe’ organised by the Ministry of Interior at the University of Cologne. ${ }^{46}$ As

\footnotetext{
${ }^{40}$ I borrow the word 'activist' from the social movement literature to define people working for a common cause-in this case for the recognition of Alevism in the diaspora. I use the term 'leading activists' as those having high levels of seniority in local, regional or national level organisations.

${ }^{41}$ Alevilerin Sesi, no. 5. (Cologne: AABF, 2002a), 11.

${ }^{42}$ Islamic radicalisation is undoubtedly dangerous for Alevis, as its results can be seen in previous massacres committed by the then radical Islamists. Gazi (1995), Sivas (1993), Çorum (1980), Maraş (1978) and Dersim (1937) massacres targeting Alevis are only the ones committed in the history of Turkish Republic. Many others were committed in the Ottoman Empire.

${ }^{43}$ Ashura is a special dish cooked when the period of Muharram fasting terminates.

${ }^{44}$ Alevilerin Sesi, no. 6. (Cologne: AABF, 2002b), 35.

${ }^{45}$ In German: Katholische Akademie zu Berlin.

${ }^{46}$ Alevilerin Sesi, no. 1. (Cologne: AABF, 2002c), 27.
} 
well, local Alevi cultural centres (AKMs) often participated in inter-faith open days along with Jewish, Christian, Orthodox, Protestant and Buddhist communities. ${ }^{47}$ In all these activities, Alevism’s peaceful approach was emphasised.

Thirdly, leading activists of AABF and of some large local organisations began to present Alevism publicly as a distinct religion, separate from Islam. Recognition as a distinct religion would enable Alevis in Germany to obtain social support but also legal and financial assistance for their institutionalisation. ${ }^{48}$ The German constitution guarantees the collective freedom of religion through self-management of religious organisations. ${ }^{49}$ Article 137.3 notes that 'religious societies shall regulate and administer their affairs independently within the limits of the law'. Article 141 also states: 'to the extent that a need exists for religious services [...] in the army, in hospitals, in prisons, or in other public institutions, religious societies shall be permitted to provide them, but without compulsion of any kind.' In Germany, religious organisations can be established as a company under corporate law or as a registered voluntary organisation, eingetragener Verein (e.V.). The statute of Körperschaft des öffentlichen Rechts (corporate body under public law) allows organisations to collect contributions (often called a church tax) to provide religious education in state schools and to be represented in media consulting committees. This status can only be obtained if the organisation can give assurance of its permanency (through the size of its membership and the length of time it has been operating). To achieve this, Alevi leaders would need to sustain community development and represent Alevism as a unique religion.

\footnotetext{
${ }^{47}$ Mario Peucker and Shahram Akbarzadeh, Muslim Active Citizenship in the West (New York: Routledge, 2014), 108. Alevilerin Sesi, no. 6-7. (Cologne: AABF, 2004), 64. Alevilerin Sesi, no. 1. (Cologne: AABF, 2002c), 28.

48 Sökefeld, Struggling for recognition.

49 See Art. 136-141.
} 
To this end, Alevi activists framed Alevism in the 2000s by emphasising its divergence from Islam in policy circles in Germany ${ }^{50}$ and through their participation in the preparation of European Accession Reports for Turkey’s membership in the European Union. The turning point came at a conference in Cologne on 23 October 2004, when activists from AABF and AABK met to evaluate the latest EU Accession report for Turkey. In that meeting, they opposed the definition of Alevis as 'non-Sunni Muslim minorities', arguing that the definition had been formulated under diplomatic pressure from the then Turkish Foreign Minister Abdullah Gül. Turgut Öker (who was then also president of AABF) and Ali Doğan (the then legal consultant for AABF) sent a letter to the European Parliament on 11 November 2004 stating that such a definition (Muslim minority) would not be acceptable to them. The Council of the EU agreed to their request and referred to them as Alevis (a distinct group) in their recommendations for Turkey. ${ }^{51}$

At the same time, activists around the country started applying for the right to conduct religious courses on Alevism at state schools. In 2000-01, AABF submitted an official request to the states of Baden-Württemberg (11 March 2000), Hessen (17 March 2000), Berlin (6 May 2000), Bayern (19 September 2000) and North Rhine-Westphalia, NRW (20 June 2001). ${ }^{52}$ In late 2000, AABF organised a meeting with teachers and the AABF activist in charge of teaching, presented the draft curriculum that they planned to use. ${ }^{53}$ In Berlin, religious classes on Alevism were accepted for the 2002-teaching year. In December 2001 state representatives from NRW, Hessen, Baden-Württemberg and Bayern requested two expert opinion reports on Alevism and AABF's capacity to supervise its teaching. Prof.

\footnotetext{
${ }^{50}$ Ayşe Ezgi Gürcan, 'Articulation \& Aggregation of Sectarian Interests: Struggle for Alevi Religious Education in Turkey and Germany’ (paper presented at the International Conference on Public Policy, Università Cattolica del Cuore, Milan, July 1-4, 2015).

${ }^{51}$ Alevilerin Sesi, no. 1. (Cologne: AABF, 2005), 24.

52 İsmail Kaplan, Alevice: Inancımız ve Direncimiz [Alevice: Our Faith and Our Resistance] (Cologne: AABF, 2009), 241.

${ }^{53}$ Alevilerin Sesi, no. 11. (Cologne: AABF, 2000), 33.
} 
Ursula Spulger-Stegemann from the University of Marburg and Prof. Stefan Muckel from the University of Cologne prepared these reports and presented them in July 2004. They concluded that Alevism is a religion in its own right, that it can be taught in schools, and that $\mathrm{AABF}$ is a religious institution as per the German Constitution 7.3. clause. ${ }^{54}$

Subsequently, courses on Alevism were initiated in Berlin (2002), Hamburg (2004), Baden-Württemberg (2006), NRW and Bavaria (2008). These are optional courses that have to be taught and graded in German. The curriculum was prepared from input from two conferences organised in November 2005 and March 2007 as well as consultation with local AKM board members, school teachers and dedes. ${ }^{55}$ The final curriculum was approved on 29 September 2007 at the AABF General Council. In 2008, there were 530 students taking courses in state schools in Germany. ${ }^{56}$ With the help of widespread promotion by AABF and growing requests by parents, by 2014 this number had almost tripled to 1490 students, with 65 teachers in 120 schools in nine states. ${ }^{57}$ In 2016, it was estimated that around 2000 students were enrolled in these courses. ${ }^{58}$ A Department of Alevism was also established at Hamburg University’s Academy of World Religions in 2015 to provide teachers with a stronger theological grounding.

In addition to introducing religious courses in schools, AABF worked on recognition of Alevism in the 2011 census, so that the Alevi population could be counted, and their

\footnotetext{
${ }^{54}$ Kaplan, Alevice: Inancımız ve Direncimiz, 241. Ursula Spuler-Stegemann, Ist die Alevitische Gemeinde Deutschland e.V. eine Religionsgemeinschaft? (Marburg: Universität Marburg, 2003).

55 Traditionally dedes are socio-religious / community leaders who lead cems, which are community gatherings where problems are discussed and resolved and where the community comes together and transcends through various rituals such as music and semah (transcendental dance). Dedes are known to have wisdom and have designated talips (students in Alevi path).

${ }^{56}$ Kaplan, Alevice: Inancimız ve Direncimiz, 249.

${ }^{57}$ Ha-ber.com, 'Almanya'da Alevilik dersleri yayılıyor' [In Germany, courses of Alevism are spreading out], 30 September 2014, http://goo.gl/dNY4HW (accessed 8 December 2017).

${ }^{58}$ CNNTurk, 'Almanlar da Alevilik dersi allyor' [Germans are also taking Alevi courses], 2 May 2016, goo.gl/eNNNu3 (accessed 2 September 2018).
} 
presence could be reflected in diversity policies. ${ }^{59} \mathrm{AABF}$ and Berlin AAKM also worked on acquiring separate areas in cemeteries for Alevis as adherents of a distinct religion. On 13 December 2001, Berlin AAKM board members successfully applied for such permission based on paragraph 3.2 of Berlin state cemetery legislation, which gives religious institutions the right to manage their own cemetery. ${ }^{6061}$ In 2002, Cologne Alevi Bektasi Cultural Centre was granted the same right to manage their own cemetery in Westfriedhof. All these developments paved the way for the Alevi diaspora in Germany to be recognised by the state as a religious institution.

Alevi activists signed an Equality of Rights Agreement with Hamburg (November 2012), a preliminary contract with the government of Lower Saxony (October 2013) and an agreement with the Bremen state government (October 2014). All of these recognise AABF as the official representative of Alevis in their state and Alevism as a distinct religion. Equality of Rights Agreements grant Alevis the right to celebrate religious holidays, to educate clerics, to open childcare centres and schools, to found Chairs in Alevism studies in universities, to participate in media consultation committees, and to have the same public recognition as Christians and Jews. The agreements were signed with state governments by the leaders of the Alevi movement in Germany identifying Alevism as a distinct religion in its own right.

\section{Construction of the Alevi Diaspora as a Congregation}

In line with the efforts of the leaders of the Alevi movement to gain official recognition, growing emphasis was given in local Alevi organisations in the 2000s in Germany. In this

\footnotetext{
59 See BDAJ, 'Zensus 2011', 2010, http://www.bdaj.net/index.php?option=com_content\&view=article\&id=224:zensus- 2011\&catid=61:aktuelles (accessed 22 June 2017).

${ }^{60}$ In German: Beleihung mit dem hoheitlichen Bestattungsrecht.

${ }^{61}$ Alevilerin Sesi, no. 11. (Cologne: AABF, 2002f).
} 
section, I argue that these efforts in Germany constituted cemaatleşme (congregation) that is a re-shaping of the Alevi movement as a religious/faith-based congregation in itself. I view cemaatleşme as activists’ efforts to represent the Alevi diaspora as having a common identity, despite their acknowledgment of internal differences, under the leadership of organisational Alevi leaders.

Cemaatleşme was evident in the following developments. Firstly, increasing numbers of organisations changed their names from Alevi Cultural Centres (AKMs) to Alevi Communities (Gemeinde in German). Their activities included weekly sohbet (conversation about Alevi ethics) gatherings and their spaces were re-defined as cemevis (places of worship) rather than dernek (organisation). For instance, in 2009, Berlin AAKM changed its name to Berlin Alevi Toplumu (BAT) [Berlin Alevi Community] in line with AABF's intention to apply for recognition as a religious institution (Körperschaft des öffentlichen Rechts). The following quote from Alevilerin Sesi-AABF's main publication-explains how important these name changes were for the movement:

'According to the [recent] decision, no organisation in Germany except AABF can use the two words Alevitische (Alevi) and Gemeinde (community) together. As such, it is established that AABF is the top establishment of the Alevi institutionalisation. The organisation founded by CEM Foundation former European coordinator Alişan Hızlı, Vereinigung der Alevitischen Gemeinden in Deutschland e.V. (Union of Alevi Communities in Germany) now has to change its name, according to Wuppertal state court's decision. AABF board member and legal consultant Eser Polat [said]: According to this decision, the name of Alevitische Gemeinde, in other words the Alevi 
community, is identified with AABF even by courts. This means that the Alevi community means AABF, and AABF means the Alevi community'. ${ }^{62}$

This name change from ‘cultural organisation' to ‘community’ is of crucial importance. When the federation was established in Germany in 1994, heated discussions prevailed about its name. The leading activists then had vehemently opposed the name Almanya Alevi Cemaatleri Federasyonu (Federation of Alevi Communities in Germany), which had been proposed by the traditionalist dedes, arguing that they were not a cemaat (congregation). This was because cemaat in Turkey referred to a religious organisation. One decade later, when they sought for recognition from the German state in the form of a religious organisation (Körperschaft des öffentlichen Rechts, which would confer important benefits), the same activists began to claim that they were the representatives of the Alevi cemaat in Germany.

Secondly, the way organisations were institutionalised was also changing. At the national level, AABF had a faith council composed of several dedes, one of whom was president. On 12 April 2003, the faith council changed its rules of association so that its membership would represent each local AKM. The importance of the role of the AABF Faith Council in the movement grew: a section of Alevilerin Sesi magazine was dedicated to explaining their activities and describing how 'correct' Alevi conduct should be. At the local level, the larger organisations established their own faith councils, constituted on the same model as that of AABF. In Cologne AKM, for instance, the rules governing the organisation were changed in 2006 to give the faith council an official role. ${ }^{63}$ Further, AABF suggested all local AKMs to appoint a dede and create a position for him in their faith council (inanç kadrosu). Accordingly, dedes working for particular AKMs should become members of that

\footnotetext{
${ }^{62}$ Alevilerin Sesi, no. 5. (Cologne: AABF, 2009b), 7.

${ }^{63}$ Alevilerin Sesi, no. 5. (Cologne: AABF, 2006a), 56.
} 
AKM and at least one dede should become a member of the administrative board and should represent their AKMs on the AABF Faith Council. Moreover, dedes should be appointed by AKMs through an agreement of service (hizmet anlaşması), should conduct annual religious services, should work in line with the decisions and suggestions of the AABF Faith Council, should participate in dede-ana training programs ${ }^{64}$ organised by the AABF Faith Council, should give service in inter-religious matters, such as inter-religious marriages, inter-religious funerals, inter-religious ceremonies and prayers, and in presenting Alevi conduct on TV and radio, should not favour their own ocak (hearth/caste), but should consider all Alevis equally. ${ }^{65}$

Thirdly, it was argued that matters of Alevi conduct (in relation, for example, to funerals, semah and cem rituals) needed to be standardised so that religious services would be the same throughout the country. According to Cafer Kaplan, the president of the AABF Faith Council (2009-2015):

'To overcome the struggles that we are facing, we need to put forward more regular worship/praying (ibadet) forms in the following process. For instance, as the Faith Council, we need to prepare a cem and erkan (conduct) file, so that all dedes conduct their work in the organisations in the same system. [...] We will call all of our organisations at the earliest possible time and ask 'do you have a dede?' After making our list, we will look at the number we have, and if we have enough numbers, we will introduce this criterion. I mean if [the dede] is from dede descent, but is not affiliated with any organisation, I believe it is not right for organisations to call on that dede. If we want to organise and grow our institution at this time, a dede needs to belong to an

\footnotetext{
${ }^{64}$ Ana is the female counterpart of dede.

${ }^{65}$ Kaplan, Alevice: Inancımız ve Direncimiz, 234-239.
} 
institution and needs to be led by an institution. Otherwise, if everyone does their work on their own, this disorder would continue. [...] When all dedes are trained in the system, [for instance] if I were unable to attend to an organisation's cem and another dede goes in my place, it would be relieving for us to know that he will conduct the cem in the same system'.66

In contrast to the existing diversity of practices among dedes, ${ }^{67}$ standardisation aimed to order and re-shape the Alevi diaspora in Germany as a single religious community.

The first step in standardising Alevi conduct was the introduction of dede-ana training programs. Such training, based on the 'project of turning to the essence [of Alevism]', began in 2002, when the AABF faith council organised a training seminar in Lauterbach for 40 participants on subjects such as 'what is Islam?' and 'what is the approach to Islam in the Alevi faith?’. ${ }^{68}$ The aim was ‘to reduce the differences between dedes because of their distinct geographical origins and to provide a regular and systematic service for all AKMs' ${ }^{69}$ The AABF Faith Council, with growing support from the administrative board, organised a number of seminars thereafter. ${ }^{70}$ On 29 April 2006, a dede-ana training program was accepted by the Faith Council. All participants in the program would receive an agreement of service (hizmet anlaşması), which gave them an official affiliation with AABF. It was also suggested that 'if dedes and anas could give their services according to a calendar for religious services (inanç hizmetleri takvimi), that would make Alevi cultural centres a real faith institution'. ${ }^{71}$ Moreover, dedes and anas were advised 'to form an Alevi code of

\footnotetext{
${ }^{66}$ Alevilerin Sesi, no. 4. (Cologne: AABF, 2006b), 54-56.

${ }^{67}$ Robert Langer, 'Alevitische Rituale', in Aleviten in Deutschland: Identitätsprozesse einer Religionsgemeinschaft in der Diaspora, ed. Martin Sökefeld (Bielefeld: Transcript, 2008), 65-108, pg. 96. ${ }^{68}$ Alevilerin Sesi, no. 3. (Cologne: AABF, 2002e), 20-21.

${ }^{69}$ Alevilerin Sesi, no. 12. (Cologne: AABF, 2002d), 23.

70 ibid.

${ }^{71}$ Alevilerin Sesi, no. 1. (Cologne: AABF, 2006c), 52.
} 
conduct and take an active role in interfaith dialogues' ${ }^{72}$ From 2006, dede-ana training programs had the objective of 'training dedes and anas who would combine the Alevi values with an institutional identity, ${ }^{73}$ for all AKMs in Germany within five years. ${ }^{74}$ Turgut Öker, the former president of $\mathrm{AABF}$ and current president of $\mathrm{AABK}$, argued that these trainings were crucial for the institutional transformation of Alevism as a religious order like that of Christians or Muslims:

'I predict that the institutionalisation process will be on the agenda within the next ten years. Institutionalisation does not only mean all institutions coming and working together. Institutionalisation also means putting forward projects that will cover decades and even hundreds of years. In this respect, in the coming period, we will make important openings in terms of faith. In the coming period, we will work to create a serious faith institution that meets the faith needs of the Alevi community, organised within our federation. We will work on reducing the local differences in faith-on the condition of preserving its richness - to the minimum level. This work of ours will not be homogenisation; on the contrary, it will enable us to strengthen the impulse to act together. As the first step in this work, dede-ana training programs will continue in the coming period too. I believe that within the next ten years, we will have an order in which dedes and anas, like priests and imams [Islamic religious leaders], will also be trained through an education system' ${ }^{75}$

As this quote makes it clear, one of the most crucial objectives of the Alevi movement in the late 2000s in Germany became standardisation of rituals and of religious leader training.

\footnotetext{
72 Alevilerin Sesi, no. 1. (Cologne: AABF, 2006c), 52.

${ }^{73}$ Alevilerin Sesi, no. 3. (Cologne: AABF, 2009c), 8-9.

${ }^{74}$ Alevilerin Sesi, no. 1. (Cologne: AABF, 2006c), 52.

${ }^{75}$ Alevilerin Sesi, no. 10. (Cologne: AABF, 2009a), 15.
} 
In addition to AABF's training programs, secondly, various opinion pieces published in Alevilerin Sesi magazine advised readers on how Alevi conduct should be. Hasan Kilavuz, the former head of the AABF Faith Council, provided detailed explanations of this conduct in his frequent writings in Alevilerin Sesi. The following account of how semah should be performed exemplifies the attempts at standardisation and re-creation of the Alevi religious community:

'They wear their folk-dance clothing as semah clothing and go dancing in public. And none of the clothing used in any organisation matches that of other organisations. Everybody uses whatever they can get based on their means. [...] Then what should be done? a) The most important task belongs to Alevi organisations. The managers of organisations need to educate member parents and young people through seminars; b) The visual and written media of Alevis should explain these issues in open forums, panel discussions and interviews; c) Alevilerin Sesi should inform its readers in every issue in a serious and informative manner; d) the AABF Faith Council should definitely explain this issue and advise people; e) All the federations of AABK should take a common decision that the young people turning [performing] semah in our organisations should wear one type of clothing, which would have the same colour and symbols, and this should continue on a long-term basis. This clothing should be simple and should have Alevi faith figures on it; f) The clothing should be professionally designed'. ${ }^{76}$

This quote suggests that semah, which was traditionally a spontaneous and instinctive practice, should be replaced by a choreographed performance that would follow the same stylistic rules throughout Germany.

\footnotetext{
${ }^{76}$ Alevilerin Sesi, no. 9. (Cologne: AABF, 2007), 44-45.
} 
Thirdly, standardisation of Alevi conduct included the introduction of an Alevi religious calendar. AABF and some local organisations have recently started using this calendar to systematise the timing of annual activities. ${ }^{77}$ Foremost among these was the celebration of the birth of Imam Ali. Just as the birth of Prophet Mohammed is celebrated among Sunnis in Kutlu Doğum Haftası (Holy Birth Week) activities, the Alevi calendar throughout the 2000s identified the birthday of Imam Ali as 21 March, which coincides with the celebrations of Nowruz. ${ }^{78}$ All these changes illustrate the Alevi movement's gradual transformation into a religious movement at the community level. Although there were widespread discussions and conflicts over the boundaries of Alevism and the rituals, some activists aimed to institutionalise Alevism on a transnational scale, as will be shown below.

\section{Institutionalisation of the World Alevi Union}

As framing contests around the definition of Alevism continued, the Alevi movement abroad in the 2010s began to evolve into a transnational movement with a clear aim of institutionalising Alevism and bringing all Alevis around the world under one umbrella. In this section, I describe the attempts by activists to develop and impose a centralised structure on Alevism under a system of transnational governance and a universally shared understanding of Alevism.

The idea of organising Alevis and managing Alevism at a supra-national level emerged in the early 2010s as a higher ambition of leading activists in Europe. The dedes of the AABF Faith Council first planned to establish a European Alevi Faith Council. On 23

\footnotetext{
77 The calendar points out the following dates as specifically important days of the year. I take the example of 2014 religious calendar. 21 March: Imam Ali’ Birth and Newroz; 11-13 February: Hızır Fast; 5-6 May: Hıdırellez; 15-16 August: Hacı Bektaş commemoration activities; 4 October: Festival of the Sacrifice; 10 October: Imam Hussain's Death; 25 October: First day of Muharrem Fasting; 6 November: Ashura Day. See for more details, http://www.Aabf-Inanc-Kurumu.com/.

${ }^{78}$ See Alevitischer Kalender for further information, http://alevi.com/de/alevitentum/alevitischer-kalender/ (accessed 8 December 2017).
} 
April 2011, dedes and anas from various European countries met in Cologne for the first time and decided to develop an integrated framework for Alevi conduct. To this end, they decided to 'centralise the decision making', to work on codes of conduct for cem, funerals, engagements and circumcision, to translate the prayers into the languages of the countries in which Alevi institutions are located. ${ }^{79}$ In their second meeting in 2011, they worked to frame their statutes and agreed that the faith-related decisions of the Faith Council in Europe should be binding for all AKMs in Europe. ${ }^{80}$

In fact, as early as 2006, Turgut Öker, the president of AABK (the Confederation of Alevi Unions in Europe), had stated that they were willing to establish a World Alevi Union. ${ }^{81}$ In early 2010, AABK established a commission specifically tasked to develop and promote institutionalisation. ${ }^{82}$ The former president of the Federation of Alevi Unions in France (FUAF), Durak Arslan, was elected as president of this new commission. After his appointment, Arslan carried out an inquiry into Alevi organisations throughout the world and started working to bring them together. He began by calling a meeting titled Dergahta Birlik (Union in the Lodge), which was held on 10-11 September 2011 in Hacıbektaş, Turkey, where he explained his plans for this new structure of Alevism to around 600 activists from all around the world. He called this process Yeni Alevi Yapılanması (YAY) [New Alevi Institutionalisation] and formulated a Küresel Alevi Birliği (KALB) [Global Alevi Union].

The proposed Küresel Alevi Birliği (KALB) had a clear structure with faith as its central element (see Figure 1.). KALB is comprised of seven musahip kurum (companion

\footnotetext{
${ }^{79}$ See Federation of Alevi Unions in Austria, ““Avrupa Alevi İnanç Kurulu” oluşturuluyor!' ['Alevi Faith Council in Europe’ is being established!], 14 July 2011, http://goo.gl/hRuALh (accessed 8 December 2017).

${ }^{80}$ Alevilerin Sesi, no. 10. (Cologne: AABF, 2011), 58.

81 ibid.

${ }^{82}$ Deniz Koşulu, 'The Alevi quest in Europe through the redefinition of the Alevi movement: recognition and political participation, a case study of the Fuaf in France', in Muslim Political Participation in Europe, ed. Jørgen S. Nielsen (Edinburgh: Edinburgh University Press, 2013), 255-76, pg. 271.
} 
institutions), a term coined by Durak Arslan. ${ }^{83}$ These would have members from all countries with a significant Alevi population, such as Turkey, the Balkans, the Middle East, Germany, France, the Netherlands, the United Kingdom, Belgium, Northern Cyprus, Austria, Switzerland, Sweden, Denmark, Norway, Italy, Australia, the USA and Canada. In Arslan’s words, this structure would reflect 'a wide community on which the sun never sets. ${ }^{84}$ It was envisaged that the project would bring together at least 500 Alevi organisations and 'would make the Alevi movement an important lobbying power in the world [policy] arena’ ${ }^{85}$

According to the model, seven different institutions would work together but the central role would be played by Alevi Inanç Merkezi (ALIM) [Alevi Faith Centre], which is located in Serçeşme, Turkey. The other institutions were the Alevi Media Union (ALMED), Alevi Artists’ Union (ALSAN), Alevi Institute (ALEN), Alevi Federations Union (ALFEB), Alevi Employers Union (ALIŞ) and Alevi Jurists Union (ALHUK). ${ }^{86}$ This structure would enable the members to enhance financial resources, produce knowledge in arts, academia and media circles and claim their communal rights in jurisdictions across the world.

\footnotetext{
${ }^{83}$ Note that the concept of musahip refers to companion families who decide to enter the Alevi path together and to look after each other throughout their life. These families ought to support each other morally and financially at all times.

${ }^{84}$ See Durak Arslan's presentation about YAY, http://goo.gl/55Ub8n (accessed 8 December 2017).

${ }^{85}$ Alevilerin Sesi, no. 5. (Cologne: AABF, 2009b), 10-11.

${ }^{86}$ Respectively, in Turkish, these are Alevi Medya Birliği (ALMED), Alevi Sanatçılar Birliği (ALSAN), Alevi Enstitüsü (ALEN), Alevi Federasyonlar Birliği (AKFEB), Alevi Iş̧verenler Birliği (ALIŞ) and Alevi Hukukçular Birliği (ALHUK).
} 


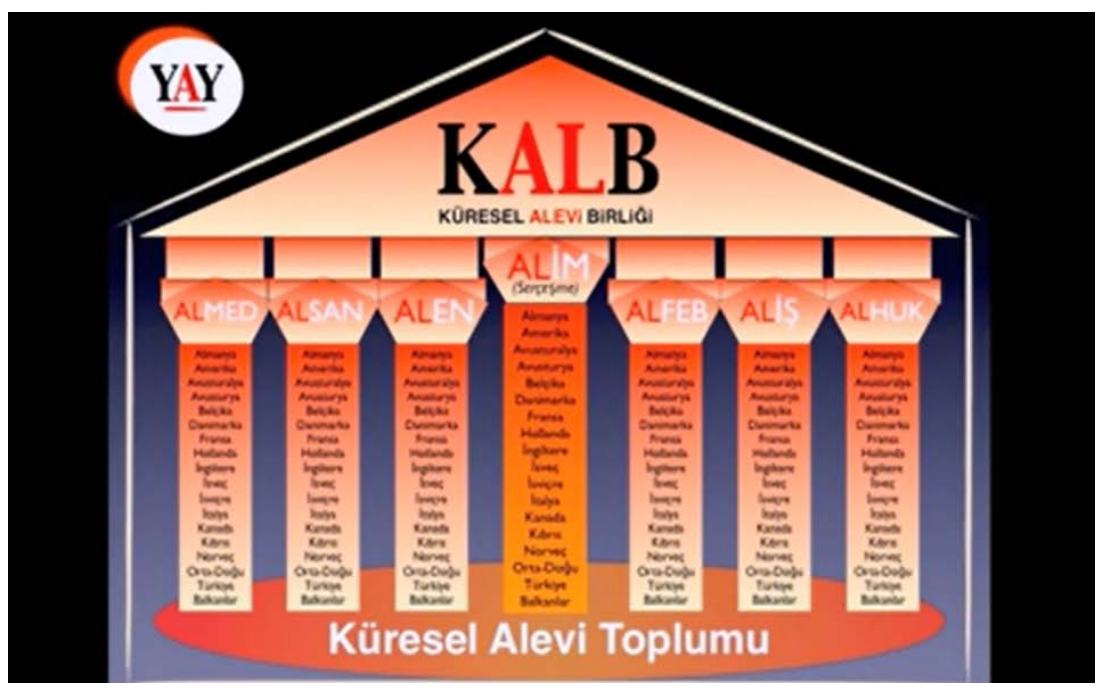

Figure 1. New Alevi Institutionalisation (YAY), Global Alevi Union (KALB)

Although the new institutionalisation has been well received, it has also attracted a number of criticisms. Firstly, reflecting the broken relationship between talips (students in the Alevi path) and dedes (socio-religious leaders), some argued that in this model dedes would acquire too much power, since they would be at the centre of the new institutionalisation. ${ }^{87}$ Secondly, some organisations, such as CEM Foundation in Turkey that is known to have right-wing nationalist tendencies, condemned the framing of Alevism in this model, arguing that Alevism should be positioned as the true form of Islam. As could be expected, bringing all organisations together under one umbrella proved to be a difficult task as they all had different views over the definition of Alevism. Thirdly, it was claimed that Serçeşme (the suggested centre for Alevi institutionalisation) was not the only place of faith, pointing out that there were a number of ocaks (hearth/caste) such as Dede Garkın, Baba Mansur, Avuçan, Sultan Sahak (located in Iran and Iraq), Haydari and Klezi (led by Arab Alevis). It was argued that locating Serçeşme as the main centre of a transnational religion would mitigate against the foundation of a truly global community. Finally, it was also

\footnotetext{
${ }^{87}$ Traditionally dedes (socio religious leaders) guide talips (students), but this relationship is not a hierarchal one. Dedes and talips are of equal status as they are dependent on each other.
} 
suggested that this institutionalisation would exacerbate exclusion and make Alevis more isolated in their countries.

There have also been some reactions to the growing emphasis on religious and faithrelated matters. The very recent workshop organised by the Alevi Bektasi Federation (ABF) on 9-11 March 2018 in Edremit, Turkey indicated that the objectives of the Alevi World Union was mostly to create a lobbying force in the world through transnational networks with Alevis around the world. The ABF President, Muhittin Yıldız, made a public speech at the end of the 3-day workshop stating that the idea of creating a World Alevi Union was originally conceived by AABK and that ABF later fully supported it. Y1ldız said that following a number of debates conducted in the workshop, the participants thought of creating unions among Alevi authors, artists, lawyers, businesspeople, pirs (spiritual guides), women and youth. These unions were thought to be organised under a delegation of Alevis who will constitute an assembly of around 120 members. The model that he described gave much less emphasis on the idea of a transnational faith centre but more on the governance mechanisms. He also insisted that the structure was open to discussion and that there was no binding decisions at this initial stage. Clearly, construction of a transnational religion needed time for reflection among its members.

\section{Conclusion}

The findings that are presented in this article suggest that the changing political landscape, social structures in the host and home countries and activists' own agency shaped the Alevi diaspora movement. The changes in Germany_-where most of the diaspora members reside-had also important ramifications for Alevis in Turkey through continuing transnational interactions between the leading activists. While institutionalising Alevism at a transnational level, members sought to systematise Alevism through standardised and 
centralised procedures. It is difficult to assess how the Alevi communities will be affected by the changes depicted in this study (such as the transformation of the training system between anas/dedes and talips from one based on common lineage towards another that is based on common membership to Alevi organisations; transformation of cem gatherings and semah rituals around aesthetic concerns; transformation of participants in these rituals towards becoming spectators; standardisation of the Alevi conduct through the establishment of Faith Councils, education in schools, training programs for community leaders in organisations, etc.) in the long term. Similarly, it is unclear how the changes of the movement's characteristics will reconstruct Alevism itself. These changes may result in the reconfiguration of the Alevi community structure and may cause the diverse views and practices to disappear. Or, the ongoing framing contests over Alevism may lead to even more novel ways of defining it. What this study does show though is that the properties of Alevism will not stay within contained spaces (such as particular traditions or institutions) but will constantly evolve according to the circumstances in which it is situated as well as members' responses to them. As the World Alevi Union continues to be established, it would be fruitful to pursue further research on how the institutionalised definitions around Alevism at a transnational level will re-shape the everyday practices in particular localities. 